\title{
Tracer Extraction Fraction
}

National Cancer Institute

\section{Source}

National Cancer Institute. Tracer Extraction Fraction. NCI Thesaurus. Code C94993.

The probability of a tracer molecule being retained in a tissue once it has entered via the bloodstream. It can be calculated by: (tracer remaining in a tissue) / (total tracer that entered on a single passage of tracer-carrying blood through it). 